\title{
Application of Elaeis guineensis Leaves in Palm Oil Mill Effluent Treatment
}

\author{
Aziela Latif, Afiza Abdullah Suhaimi* and Rohayu Ahmmad Romzay \\ Department of Occupational Safety and Health, Faculty of Technology \\ Universiti Malaysia Pahang, Lebuhraya Tun Razak, 26300, Kuantan, Pahang Darul Makmur; \\ afiza@ump.edu.my
}

\begin{abstract}
Palm Oil Mill Effluent (POME) is a highly polluting wastewater that pollutes the environment if discharged directly Owing to its high Chemical Oxygen Demand (COD) and Biochemical Oxygen Demand (BOD) concentration. This study utilizes Elaeis guineensis leaves in POME treatment to reduce the COD, BOD, and to remove colour and comply with the Department of Environment (DOE) discharge standard limit. Batch biosorption experiments were carried out for the removal of Azo dye, (A052) using E. guineensis leaves as a potential biosorbent. The effects of various parameters, such as $\mathrm{pH}$, mass of biosorbent, initial concentration, and contact time were studied to evaluate and optimize the biosorption process condition. The optimum conditions were fixed at $\mathrm{pH} 2,90$ minutes of contact time, $80 \mathrm{ppm}$ of initial concentration, and $1.0 \mathrm{~g}$ amount of biosorbent. This optimum condition was then applied for COD, BOD and colour removal in POME. Under the optimum condition, maximum percentage reduction of COD, and BOD was found to be $82 \%$ and $44 \%$ respectively, and percentage of colour removal stood at $91.6 \%$. While no standard discharge limit is stipulated for COD, the result shows that the final concentration of BOD does not comply with the standard discharge limit, specified by Environment Quality (Prescribed Premises) (Crude Palm Oil) regulations, 1977. Langmuir and Freundlich models were applied to describe the experimental data. Experimental data fitted very well with the Langmuir isotherm model. It indicates that the biosorption mechanism of E. guineensis occurs on a homogenous surface through monolayer biosorption. Further, this study reveals that E. guineensis can effectively, be used as biosorbent as the the alternative treatment of COD, BOD and color removal in POME.
\end{abstract}

Keywords: Agricultural Waste, Biosorption, BOD, COD, Colour, POME

\section{Introduction}

The palm oil industry is one of the major agro-industries, and one of the main agricultural products in Malaysia. According to Ahmad et $\mathrm{al}^{1}$, the Malaysian oil palm industry had been recorded as one of the largest producer and exporter of palm oil in the world. Thus, this rapid development of the palm oil industries in Malaysia over the years produced high amount of POME. Concurrent to this huge amount of production, voluminous highly polluting wastewater referred to as POME was produced and caused some environmental concerns. POME is a high strength organic wastewater, which, adversely, affects aquatic life as well as human life directly or indirectly ${ }^{2}$. Thus, it had to be treated efficiently to alleviate environmental hazards.

If this effluent is discharged untreatably, it could certainly give rise to considerable environmental problems owing to its high $\operatorname{BOD}(25,000 \mathrm{mg} / \mathrm{L}), \operatorname{COD}(53,630 \mathrm{mg} / \mathrm{L})$, and oil and grease $(8370 \mathrm{mg} / \mathrm{L})^{3}$. Residue oil was one of the key ingredients of POME that leads to the high COD and $\mathrm{BOD}$ values. $\mathrm{COD}$ and BOD parameters were identified as the major problem in POME${ }^{4}$. Therefore, it could cause pollution of waterways due to oxygen depletion, and other related effects as reported by Ahmad et al ${ }^{1}$.

According to Hwang et al. ${ }^{5}$ and $\mathrm{Wu}$ et al. ${ }^{6}$, the palm oil mill industry in Malaysia was identified as the one that produces the largest pollution, and POME was the 
major sources of aquatic pollution that is released into the rivers throughout the country. Due to increasing menace of pollution, many POME control measures are suggested. Accordingly, Environmental Quality Act 1974 promulgated several regulations in order to control and monitor the discharge of effluent from Crude Palm Oil (CPO) industry, besides other environmental controls, for instance, the Environmental Quality (Prescribed Premises) (Crude Palm Oil) Order, 1977, and the Environment Quality (Prescribed Premises) (Crude Palm Oil) regulations, $1977^{1}$.

An efficient treatment is highly desirable in all palm oil mills in order to control the discharge of effluent into any water bodies. The final discharged wastewater had to conform to the standard parameters, set by the DOE. Thus, several innovative treatment technologies had been explored, and applied by palm oil mill to treat POME. Presently, most of palm oil mills had adopted conventional biological treatments of anaerobic or facultative digestion, which needs large treatment area, long treatment periods, and high cost for maintenance. Realizing the adverse effect of this effluent to the environment, measures to counter pollution had been deployed. Therefore, a new and improved POME treatment technology would be required to meet standard discharge limits. Hence, the need for efficient treatment of POME wastewater was critically warranted in all palm oil mills in order to control the discharge of effluent into any river. Thus, this study is specifically designed to apply another alternative for POME treatment by using the Elaeis guineensis leaves in POME treatment so as to reduce the COD, BOD, and to remove colour, thereby complying with the DOE discharge standard limit.

\section{Materials and Methods}

\subsection{Biosorbent Material}

POME samples were obtained from a selected palm oil mill in Kuantan, Pahang. Elaeis guineensis leaves that were used as biosorbent in this study were collected from a selected palm plantation in Kuantan, Pahang. Only palm tree leaves that classified as Pelepah 17 by Felda were used for this study. The E. guineensis leaves were washed thoroughly with distilled water to remove dust, dirt, and any unwanted particles. The washed materials were then completely dried in an oven at $70^{\circ} \mathrm{C}$ for $24 \mathrm{~h}$. After that, the leaves were grinded to fine powder using a cutting machine and sieved to obtain constant size at $50 \mu \mathrm{m}$. The powdered biosorbent was stored in an airtight container for further use. No other chemical and physical treatments were carried out, prior to biosorption treatment. The Figure 1 shows the summary of the treatment.

\subsection{Dye Solution Preparation}

The dye used in the study is AO52. The dye stock solution was prepared by dissolving appropriate amount of $\mathrm{AO} 52$ in $500 \mathrm{~mL}$ distilled water, and the test solutions were prepared by diluting the dye stock solution to the required concentrations $(20,40,60,80$ and $100 \mathrm{mg} / \mathrm{L})$. The $\mathrm{pH}$ of solutions was adjusted with $0.1 \mathrm{~N} \mathrm{HCL}$ and $0.1 \mathrm{~N} \mathrm{NaOH}$ using a $\mathrm{pH}-$ meter.

\subsection{Batch Experiment}

All experiments were carried out with the biosorbent sample in $100 \mathrm{~mL}$ conical flasks containing $50 \mathrm{~mL}$ AO52 to evaluate the experimental parameters such as $\mathrm{pH}$, amount of biosorbent, dye concentration, and contact time. The ranges of these parameters are given in Table 1. After each biosorption process, the dye solution was separated from the biosorbent by centrifugation at $200 \mathrm{rpm}$ for 25 minutes for solid-liquid separation, and the residual dye concentration in solution was analyzed by a UV-Vis spectrophotometer at $530 \mathrm{~nm}$. The amount of biosorption, $\mathrm{q}(\mathrm{mg} / \mathrm{g})$ was calculated using the equation which is as follows

$$
q=\frac{(C o \mid C e) V}{M}
$$

where, $\mathrm{Co}$ and $\mathrm{Ce}$ are the initial and equilibrium concentrations of dye $\left(\mathrm{mgL}^{-}\right)$, respectively. $\mathrm{V}$ is the volume (L) of the solution and $\mathrm{M}$ is the amount $(\mathrm{g}$ ) of biosorbent used.

The removal efficiency percentage was calculated as:

$$
\text { Removal percentage }=\%=\frac{C o \mid C t}{C o} \times 100
$$

where, $\mathrm{Ct}\left(\mathrm{mgL}^{-1}\right)$ is the dye concentration at time $t$ (min).

Table 1. The summary of batch experimental parameters

\begin{tabular}{lccc}
\hline $\mathrm{pH}$ & Biosorbent dosage & Dye concentration & Contact time \\
\hline $2-10$ & $0.2-1.2 \mathrm{~g}$ & $20-100 \mathrm{mgL}^{-1}$ & $5-120 \mathrm{~min}$ \\
\hline
\end{tabular}




\subsection{Sampling Test}

For the purpose of the study, a few parameters had been taken into consideration for analysis, which include BOD, $\mathrm{COD}$ and colour removal. The tests during the experimental study were carried out, while strictly observing the guidelines, set by APHA Standard Method (20 ${ }^{\text {th }}$ Edition)Examination for water and wastewater ${ }^{7}$ (Table 2$)$.

\subsection{Data Analysis}

\subsubsection{BOD Analysis}

The formula to determine the BOD is given in Equation 3, where, P represents Dilution Factor, Vs is the Volume of

Table 2. The summary methods of sampling test

\begin{tabular}{ll}
\hline Parameters & \multicolumn{1}{c}{ Test } \\
\hline BOD & Standard method APHA 5210-B \\
COD & Standard method APHA 5220-C \\
Color Removal & Standard method APHA 2120-C \\
\hline
\end{tabular}

Sample, Vdw is Volume of Dilution Water, DO1 and DO5 are the initial DO of the diluted sample $(\mathrm{mg} / \mathrm{L})$ and final DO of diluted sample after incubation $(\mathrm{mg} / \mathrm{L})$ respectively.

$$
\begin{aligned}
& \mathrm{P}=\frac{V s}{(V s+V d w)} \\
& \mathrm{BOD}_{5}=\frac{(D o 1-D o 5)}{P}
\end{aligned}
$$

Then, the $\mathrm{BOD}_{3}$ was calculated to compare with the Effluent Discharge Standards for crude palm oil mills. The formula is given in Equation 4.

$$
\begin{aligned}
& \mathrm{BOD}_{\mathrm{L}}=\mathrm{Lo}\left(1-e^{-k t}\right) \\
& \mathrm{BOD}_{3}=\operatorname{Lo}\left(1-e^{-k t}\right)
\end{aligned}
$$

Where, Lo is Ultimate BOD $(\mathrm{mg} / \mathrm{L})$ and $\mathrm{K}$ is the BOD Rate Constant.

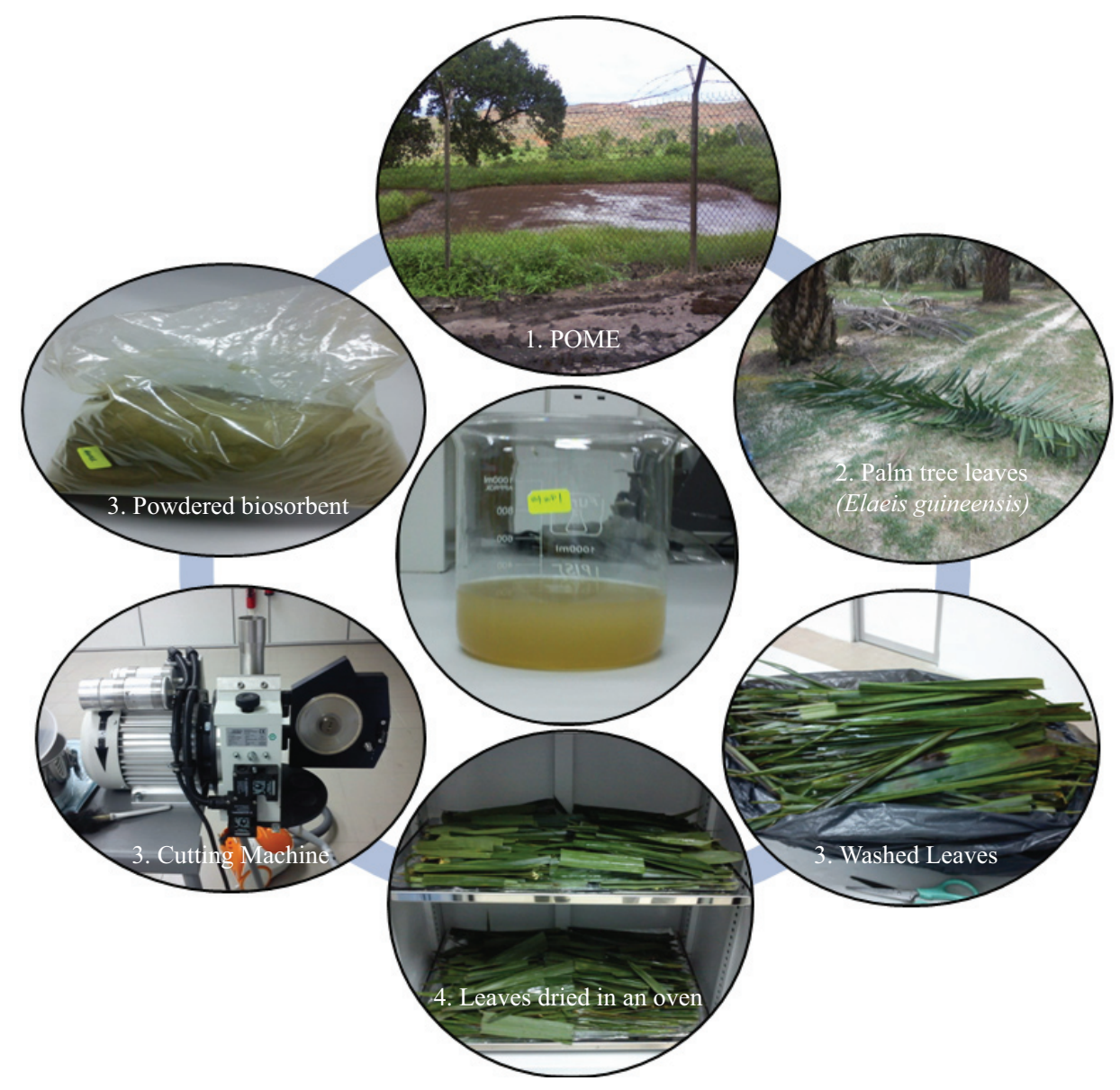

Figure 1. The summary of the treatment process. 


\section{Results and Discussions}

\subsection{Effect of $\mathrm{pH}$ Solution}

The $\mathrm{pH}$ solution has significant effect on the surface charge of the biosorbent, the degree of ionization of dye molecules, and the colour of the dye solution ${ }^{8,9}$. To analyze the influence of $\mathrm{pH}$ on the biosorption capacity of E. guineensis for A052 dye, the experiments were carried out at different initial solution $\mathrm{pH}$ values varying from 2 to 10. The results are depicted in Figure 2. This figure indicates that the biosorption capacity decreased significantly with an increase in $\mathrm{pH}$ of the solution, Further, the maximum colour removal of $92.9 \%$ was achieved at $\mathrm{pH} 2$.

It is well known that in acidic condition, more protons will be available to protonate the biosorbent surface, thereby increasing the electrostatic attractions between negatively charged dye anions and positively charged adsorption sites, facilitating an increase in the dye adsorption $^{10,11}$. Hence, the optimum $\mathrm{pH}$ for AO52 biosorption by Elaeis guineensis leaf was fixed at $\mathrm{pH} 2$, and was used for further studies.

\subsection{Effect of Amount of Biosorbent}

Amount of biosorbent is an important parameter influencing biosorption process, since it determines the biosorption capacity of a biosorbent for a given initial concentration of the adsorbate at the operating conditions $^{12}$. The effect of a different amount of the biosorbent on the percentage removal of Azo dye was carried out at different range from 0.2 to $1.2 \mathrm{~g}$ and the results are shown in Figure 3. It can be seen that the removal percentage of A052 increases with the increase of biosorbent. The percentage removal efficiency of AO52 increased from 5.5\% to $42.76 \%$ with an increase in the amount of biosorbent from 0.2 to $1.2 \mathrm{~g}$ respectively. This is due to the increase of biosorbent surface area and the availability of more biosorption sites ${ }^{13,14}$. Maximum dye removal of $42.76 \%$ is observed at $1.0 \mathrm{~g}$, and was chosen for other biosorption studies.

\subsection{Effect of Initial Dye Concentration}

The initial concentration provides a significant driving force to overcome all mass transfer resistances of all molecules between the aqueous and the solid phases ${ }^{15,16}$. Biosorption of $\mathrm{AO} 52$ onto the leaf powder was carried out at different initial dye concentration in the ranges of 20 to $100 \mathrm{mg} / \mathrm{L}$. The results are illustrated in Figure 4. It shows that percentage removal of dye decreases with increase in initial concentration. The percentage removal of A052 decreased from $56 \%$ to $29 \%$ as the initial concentration of the dye increased from 20 to $100 \mathrm{mg} / \mathrm{L}$.

According to Aksu \& Kabasakal ${ }^{17}$, at lower dye concentration, solute concentrations to biosorbent sites ratio is higher that causes an increase in color removal. Conversely, at higher concentration, more dye molecules are left unabsorbed in the solution due to the saturation of binding sites, resulting in decreased dye removal percentage $^{18}$. Even though the percentage removal decreased with the higher concentration, the previous studies by Donmez and $\mathrm{Aksu}^{19}$ and Banat et al. ${ }^{20}$ revealed that a higher initial dye concentration of dye will enhance the biosorption process. So, the optimum condition was taken at initial concentration of $80 \mathrm{mg} / \mathrm{L}$.

\subsection{Effect of Contact Time}

In the wastewater treatment process, the contact time between the dye molecules and the biosorbent is notably important for practical application ${ }^{21}$. The effects of contact time on the percentage removal of AO52 by the Elaeis guineensis leaf were studied for different contact time in the range of 5-120 min, and the results are given in Figure 5. It was found that the percentage removal of AO52 gradually increased with contact time in the first $75 \mathrm{~min}$, and attained equilibrium within 90 minutes at removal efficiency of $52 \%$, which is enough to adsorb maximum amount of the dye from the solution. The rapid biosorption and percentage removal is probably due to the abundant availability of active sites on the biosorbent surface ${ }^{11}$ during the first 75 minutes. Therefore, 90 minutes was selected as the optimum contact time for all further experiments.

\subsection{Wastewater Parameter Analysis}

\subsubsection{BOD Analysis}

The effect of E. guineensis on the BOD reduction in POME was carried out at optimum set condition: $\mathrm{pH} 2$, contact time $90 \mathrm{~min}, 1.0 \mathrm{~g}$ amount of biosorbent, and $80 \mathrm{ppm}$ initial concentration. The wastewater was treated with E. guineensis leaves at optimum condition and its BOD concentrations were measured before and after treatment with the biosorbent.

The results are shown in Table 3. It shows that, there is reduction in $\mathrm{BOD}$ in the treated POME as compared to before the treatment. The reduction in BOD was $205 \mathrm{mg} / \mathrm{L}$ 


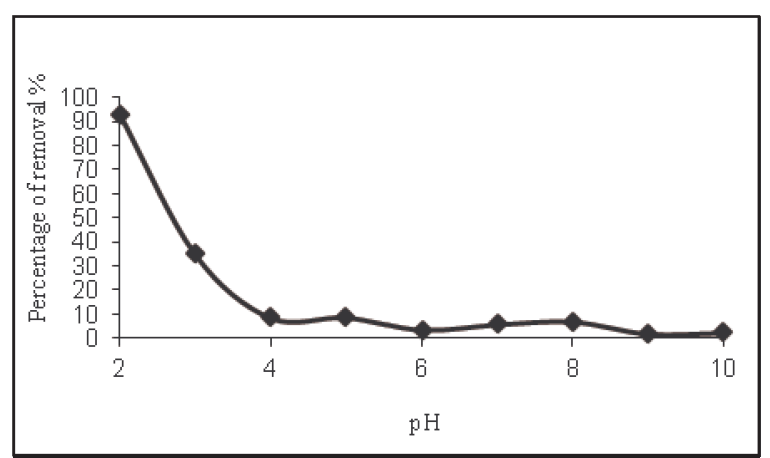

Figure 2. The percentage removal of AO52 against different $\mathrm{pH}$.

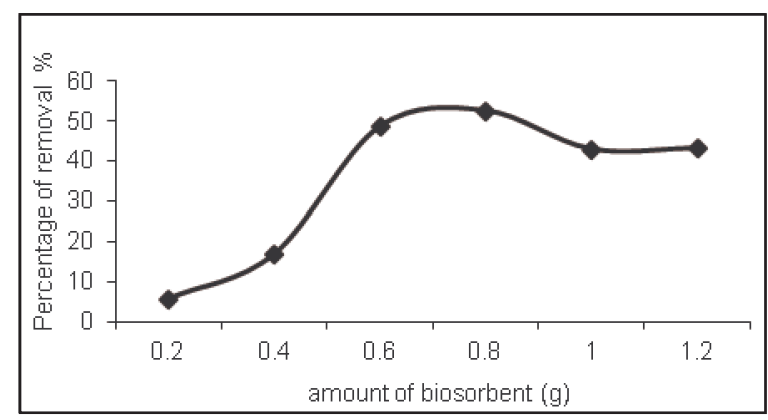

Figure 3. Th e percentage removal of AO52 against different amount of biosorbent.

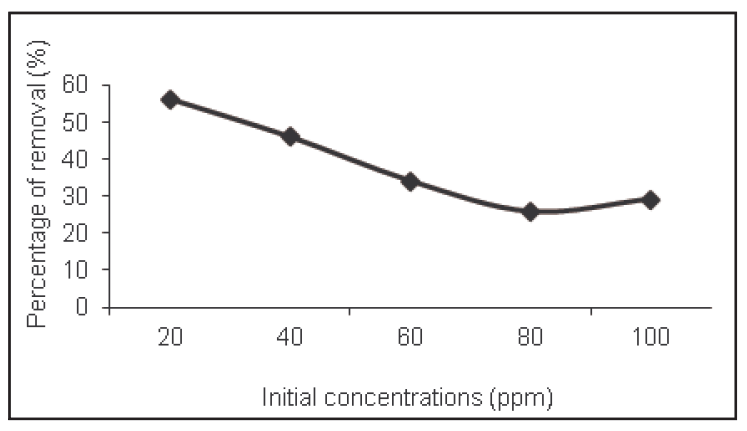

Figure 4. Th e percentage removal of AO52 against different initial concentration.

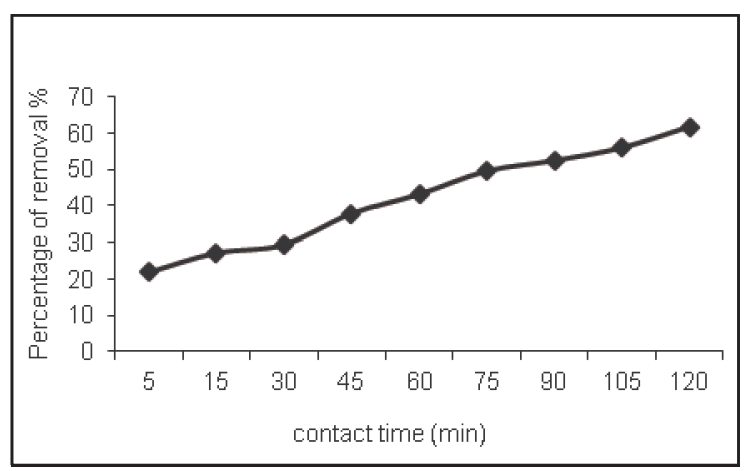

Figure 5. Th e percentage removal of AO52 against different contact time. before the treatment to $114 \mathrm{mg} / \mathrm{L}$ after the treatment and the percentage removal was calculated to be $44 \%$. Similar results were reported by Devi et al. $^{22}$, who assessed the reduction of $\mathrm{BOD}$ of wastewater from coffee processing plant using Avocado Peels.

Th en, the final concentration of BOD were compared with the standard discharge limit of Environment Quality (Prescribed Premises) (Crude Palm Oil) regulations, 1977. It was found that, the final BOD concentrations were very high as compared to the standard discharge limit of $100 \mathrm{mgL}^{-1}$ as prescribed by DOE. Based on the results, it shows that the E. guineensis leaves are not very effective for removal of BOD in POME.

\subsubsection{COD Analysis}

Th e COD test is commonly used to indirectly measure the amount of organic compounds in water. Th e per centage of COD reduction was studied at the optimum fixed parameters: $\mathrm{pH} \mathrm{2,} 90$ min of contact time, and 1.0 $\mathrm{g}$ amount of biosorbent, and 80ppm of initial concentration. Th e results are presented in Table 4 . Th e results show that the COD concentration decreased in the treated POME as compared to the untreated wastewater, the reduction in COD was from $2315 \mathrm{mgL}^{-1}$ (raw POME) to $398 \mathrm{mgL}^{-1}$ (treated POME) with a percentage of removal effi ciency of $82 \%$.

Th e concentration of COD remaining after treat ment was then compared with the standard discharge of Environment Quality (Prescribed Premises) (Crude Palm Oil) regulations, 1977. According to the Environmental Quality Act (EQA 1974, 2010), there is no discharge standard limit for COD after 1984. Th us, basically the final concentration of COD after treatment is safe for discharge to the river due to the higher percentage removal

Table 3. BOD test result $(\mathrm{mg} / \mathrm{L})$

\begin{tabular}{lccc}
\hline \multicolumn{3}{c}{ Biochemical Oxygen Demand $(\mathrm{mg} / \mathrm{L})$} \\
\hline Sample & Before treatment & Aft er treatment & $\begin{array}{c}\text { Percentage } \\
\text { removal \% }\end{array}$ \\
\hline POME & 205 & 114 & $44 \%$ \\
\hline
\end{tabular}

Table 4. COD test result $(\mathrm{mg} / \mathrm{L})$

\begin{tabular}{lccc}
\hline \multicolumn{4}{c}{ Chemical Oxygen Demand $(\mathrm{mg} / \mathrm{L})$} \\
\hline Sample & Before treatment & Aft er treatment & $\begin{array}{c}\text { Percentage } \\
\text { removal \% }\end{array}$ \\
\hline POME & 2315 & 398 & $82 \%$ \\
\hline
\end{tabular}


efficiency. Thus, it shows that E. guineensis leaves are effective for removal of COD from the wastewater.

\subsubsection{Color Analysis}

The percentage color removal of POME was studied using the fixed optimum parameters: $\mathrm{pH} 2$, contact time of 90 minutes, $1.0 \mathrm{~g}$ amount of biosorbent, and $80 \mathrm{ppm}$ of initial concentration. The results are presented in Table 5. The results indicated that the concentration of color decreased in the treated POME as compared to the untreated wastewater.

The reduction was from $316.954 \mathrm{mg} / \mathrm{L}$ (raw POME) to $26.533 \mathrm{mg} / \mathrm{L}$ (treated POME) with a percentage of removal efficiency of $91.6 \%$. Figure 6 and 7 shows the color of POME before and after treatment. Thus, it is evident that E. guineensis leaves are very effective for the removal of color in POME.

\subsection{Biosorption Isotherm}

Biosorption isotherms describe how adsorbate interacts with biosorbents, and it is measured to determine

Table 5. Color removal test result (mg/L)

\begin{tabular}{lccc}
\hline \multicolumn{4}{c}{ Colour Removal test $(\mathrm{mg} / \mathrm{L})$} \\
\hline Sample & Before treatment & After treatment & $\begin{array}{c}\text { Percentage } \\
\text { removal \% }\end{array}$ \\
\hline POME & 316.954 & 26.533 & $91.6 \%$ \\
\hline
\end{tabular}

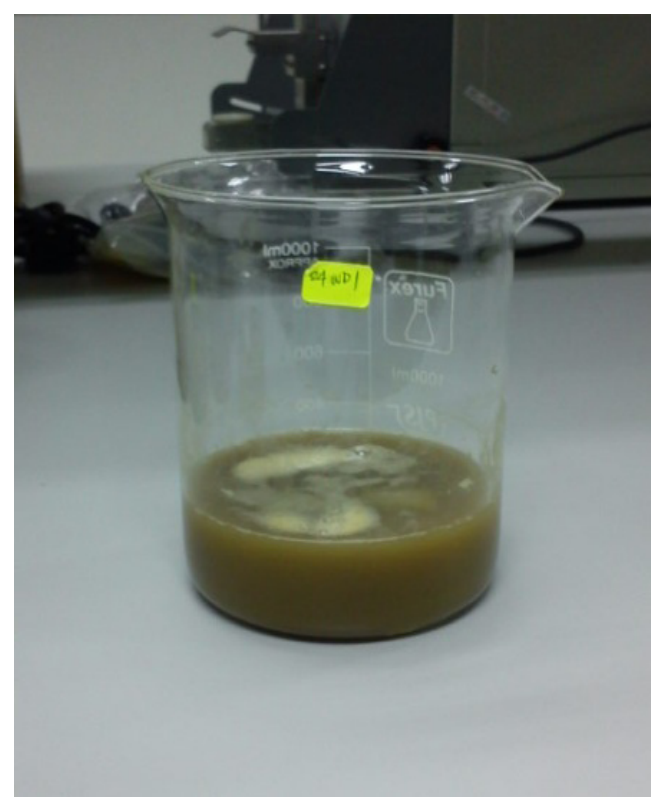

Figure 6. Colour of untreated POME. the capacity of the biosorbent for adsorbate ${ }^{23}$. The equilibrium biosorption isotherms are the most important to understand the mechanism of biosorption system. The equilibrium studies were carried out at $\mathrm{pH} 2$, amount of biosorbent of $1 \mathrm{~g}$, dye concentration of $80 \mathrm{mg} / \mathrm{L}$, and contact time of 90 minutes. The equilibrium data were analyzed by the most commonly used isotherms; Langmuir Isotherm and Freundlich isotherm ${ }^{24}$.

The Langmuir isotherm model suggests that that biosorption takes place at specific homogenous sites within the biosorbent. Once a biosorbate occupied a binding site, no further biosorption occurs at this site. In other words Langmuir model assumed that biosorbed layer was one molecule thickness (monolayer biosorption). The linear form of the Langmuir model ${ }^{25,11}$ is presented by the following equation:

$$
\frac{C e}{q e}=\frac{1}{b q m}+\frac{C e}{q m}
$$

where, qm shows monolayer biosorption capacity of the biosorbent $(\mathrm{mg} / \mathrm{g}), \mathrm{b}$ is the Langmuir constant $\left(\mathrm{Lmg}^{-1}\right)$ $\mathrm{Ce}$ is equilibrium concentration of the adsorbate in the solution $(\mathrm{mg} / \mathrm{L})$ and qe is amounts of adsorbate sorbed onto biosorbent at equilibrium (mg/g). The plot of Ce/qe versus Ce was drawn to generate the intercept value of 1 / bqm, and the slope of 1/qm (Figure 8).

The Freundlich isotherm, on the other hand, assumes that the biosorption process took place on heterogenous

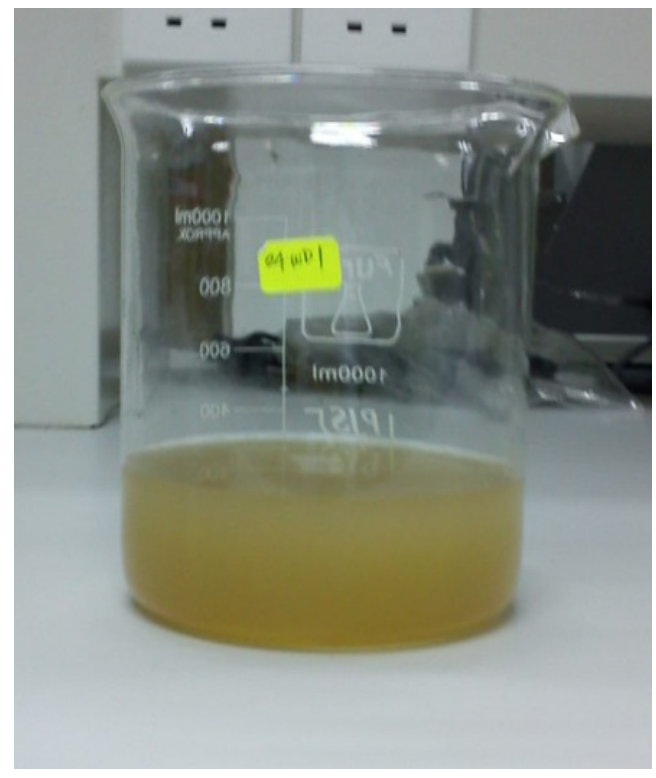

Figure 7. Colour of treated POME. 
surface, and also possibly in multilayer biosorption mode. Th e Freundlich modę ${ }^{11}$ could be expressed as:

$$
\ln q e=\ln K f+\frac{1}{n f} \ln C e
$$

where, Kf represents the relative biosorption capacity of biosorbent $(\mathrm{mg} / \mathrm{g})\left(\mathrm{mgL}^{-1}\right)^{-1 / \mathrm{n}}, \mathrm{nf}$ is a constant related to biosorption intensity (dimensionless). Th e plot of ln qe versus $\ln \mathrm{Ce}$ is shown in Figure 9. Th e Langmuir and Freundlich isotherm constant and the correlation coefficients $\mathrm{R}^{2}$ is presented in Table 6.

Based on the linear regression correlation coeffi cient, $\mathrm{R}^{2}$, the equilibrium data were well fitted by the Langmuir isotherm. Th is result indicates that the biosorption takes place at specific homogenous sites within the biosorbent surface with uniform distribution energy. Once a dye molecule occupies a site, no further biosorption can take place at that site. It shows that the biosorption of A052

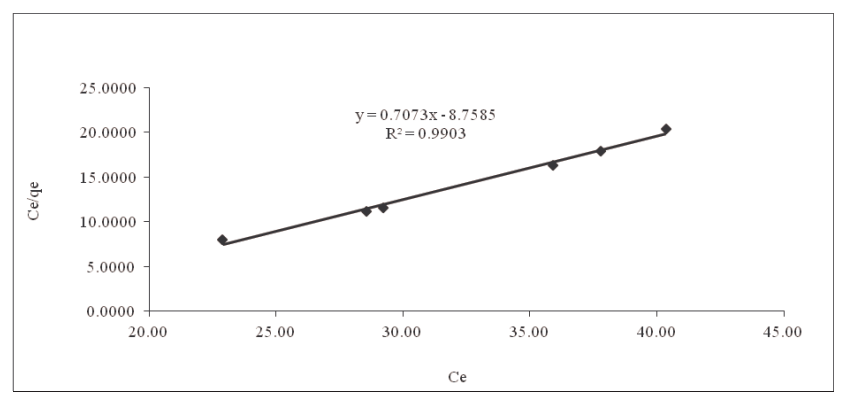

Figure 8. Langmuir isotherm model.

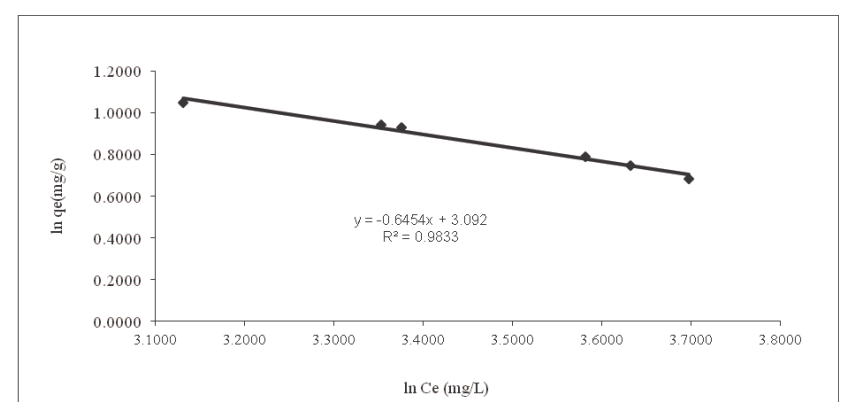

Figure 9. Freundlich isotherm model.

Table 6. Th e Langmuir and Freundlich isotherm constant and the correlation coeffi cients

\begin{tabular}{ccccccc}
\hline Sample & \multicolumn{2}{c}{$\begin{array}{c}\text { Langmuir isotherm } \\
\text { coeffi cients }\end{array}$} & \multicolumn{3}{c}{$\begin{array}{c}\text { Freundlich } \\
\text { isotherm } \\
\text { coeffi cients }\end{array}$} \\
\hline $\mathrm{AO52}$ & $\mathrm{qm}(\mathrm{mg} / \mathrm{g})$ & $\mathrm{b}\left(\mathrm{L} \mathrm{mg}^{-1}\right)$ & $\mathrm{R}^{2}$ & $\mathrm{~K}_{\mathrm{f}}$ & $\mathrm{n}$ & $\mathrm{R}^{2}$ \\
& 1.867 & 0.226 & 0.990 & 22.021 & 1.550 & 0.983 \\
\hline
\end{tabular}

onto Elaeis guineensis leaves follows Langmuir model better than Freundlich isotherm.

\section{Conclusion}

Th is study is specifically designed to evaluate the potential of utilising Elaeis guineensis as a natural biosorbent for the possible treatment of COD, BOD and color removal in POME thereby conforming to the DOE discharge standard limit. Th is agricultural waste biomass is cheap and easily available material that can become an environmentally friendly alternative or complement to the more commonly used methods for effl uent treatment $\hat{p}^{7}$.

Biosorption studies were conducted to evaluate and optimize the effects of $\mathrm{pH}$, amount of biosorbent, initial concentration, and contact time on percentage removal of Acid Orange (AO52) in order to find the optimum condition for further treatment in POME.

Th e experimental results showed that, the percentage removal of the dye increased with the increase in contact time and amount of biosorbent, while it decreased with the increase in $\mathrm{pH}$ and initial dye concentration. So the optimum parameters were fixed at $\mathrm{pH} 2,1.0 \mathrm{~g}$ amount of biosorbent, $80 \mathrm{ppm}$ initial concentration, and 90 minutes for contact time for the reduction of COD, BOD, and the colour removal of POME.

While for the COD and BOD, it is found that the removal percentage for BOD is only $44 \%$ and for COD $82 \%$. Obviously, the final concentration of BOD does not meet the DOE discharge standard limit. Besides, for $\mathrm{COD}$, there is no stipulated discharge limit for POME, at the same time, it is effi ciently reduced to attain a higher percentage removal. Th e removal percentage for colour is 91.6\%. Th e equilibrium data were best described by the Langmuir isotherm model. It becomes clear that the biosorption takes place at specific homogenous sites within the biosorbent surface with uniform distribution energy.

Th erefore, it can be concluded that thElaeis guineensis leaves can be used very effi ciently to remove COD and color in POME, though not very effi cient to remove BOD. In short, the Elaeis guineensis leaves can be used as an economical natural biosorbent to remove COD, $\mathrm{BOD}$ and color in POME.

\section{References}

1. Ahmad AL, Ismail S, Bhatia S. Water recycling from Palm Oil Mill Effl uent (POME) using membrane technology. Desalination. 2003; 157(1-3):87-95. 
2. Alade AO, Jameel AT, Muyibi SA, Abdul Karim MI, Zahangir Alam M. Application of semifluidized bed bioreactor as novel bioreactor system for the treatment of Palm Oil Mill Effluent (POME). African Journal of Biotechnology. 2011; 10(81):18642-48.

3. Ma AN. A novel treatment for palm oil mill effluent, Palm Oil Res. Institute Malaysia (PORIM). 1995; 29:201-12.

4. Ma AN. Palm diesel: an option for greenhouse gas mitigation in the energy sector. Journal of Oil Palm Research. 2000a; 17(1):47-52.

5. Hwang TK, Ong SM, Seow CC, Tan HK. Chemical composition of palm oil mill effluents. The Planter. 1978; 54 (2):749-56.

6. Wu TY, Mohammad AW, Jahim JM, Anuar N. Pollution control technologies for the treatment of Palm Oil Mill Effluent (POME) end-of-pipe processes. J Environ Manage. 2010 Jul; 91(7):1467-90.

7. American Public Health Association (APHA). Standard methods for the examination of water and wastewater. $20^{\text {th }}$ edition. Washington, D.C.: American Public Health Association, American Water Works Association, and Water Pollution Control Federation; 1999.

8. Nuhoglu Y, Oguz E. Removal of copper (II) from aqueous solutions by biosorption on the cone biomass of Thuja orientalis. Process Biochem. 2003; 38(11):1627-31.

9. Yao ZY, Qi JH, Wang LH. Equilibrium, kinetic and thermodynamic studies on the biosorption of $\mathrm{Cu}$ (II) onto chestnut shell. J Hazard Mater. 2010 Feb 15; 174(1-3): 137-43.

10. Chiou MS, Chuang GS. Competitive adsorption of dye metanil yellow and RB15 in acidic solutions on chemically cross-linked chitosan beads. Chemosphere. 2006 Feb; 62(5):731-40.

11. Deniz F, Karaman S. Removal of Basic Red 46 dye from aqueous solution by pine tree leaves. Chem Eng J. 2011; 170(1):67-74.

12. Chowdhury S, Chakraborty S, Saha P. Biosorption of basic green 4 from aqueous solution by Ananas comosus (Pineapple) leaf powder. Colloids Surf B: Biointerfaces. 2011 Jun 1; 84(2):520-27.

13. Jaikumar V, Ramamurthi V. Biosorption of acid yellow by spent brewery grains in a batch system: equilibrium and kinetic modelling. International Journal of Biology. 2009 Jan; 1(1):21-29.
14. Nasuha N, Hameed BH, Mohd Din AT. Rejected tea as a potential low-cost adsorbent for the removal of methylene blue. J Hazard Mater. 2010; 175(1-3):126-132.

15. Ho YS, Chiang TH, Hsueh YM. Removal of basic dye from aqueous solution using tree fern as a biosorbent. Process Biochem. 2005; 40(1):119-24.

16. Dogan M, Alkan M, Demirbas O, Ozdemir Y, Ozmetin C. Adsorption kinetics of maxilon blue GRL onto sepiolite from aqueous solutions. Chemical Engineering Journal. 2006; 124(1-3):89-101.

17. Aksu Z, Kabasakal E. Batch adsorption of 2, 4-dichlorophenoxyacetic acid (2,4-D) from aqueous solution by granular activated carbon. Separ Purif Tech. 2004; 35(3):223-40.

18. Ozer AG, Akkaya G, Turabik M. Biosorption of Acid Red 274 (AR274) on Enteromorpha prolifera in a batch system. J Hazard Mater. 2005 Nov 11; 126(1-3):119-127.

19. Donmez G, Aksu Z. Removal of chromium (VI) from saline wastewaters by Dunaliella species. Process Biochem. 2002; 38(5):751-62.

20. Banat F, Al-Asheh S, Al-Makhedmeh L. Evaluation of the use of raw and activated date pits as potential adsorbents for dye containing water. Process Biochem. 2003 Oct; 39(2):193-202.

21. Hamdaoui O, Saoudi F, Naffrechoux E, Chiha M. Sorption of malachite green by a novel sorbent, dead leaves of plane tree: equilibrium and kinetic modeling. Chem Eng J. 2008 Sep; 143(1-3):73-84.

22. Devi R, Singh V, Kumar A. COD and BOD reduction from coffee processing wastewater using avocado peel carbon. Bioresour Technol. 2008 Apr; 99(6):1853-60.

23. Feng N, Guo X, Liang S, Zhu Y, Liu J. Biosorption of heavy metals from aqueous solutions by chemically modified orange peel. J Hazard Mater. 2011 Jan; 185(1):49-54.

24. El-Naas MH, Al-Zuhair S, Abu Alhaija M. Reduction of COD in refinery wastewater through adsorption on date-pit activated carbon. J Hazard Mater. 2010 Jan 15; 173(1-3):750-57.

25. Langmuir I. The adsorption of gases on plane surfaces of glass, mica and platinum. J Am Chem Soc. 1918; 40(9):1361-1403.

26. Freundlich H. Over the adsorption in the solution. J Phys Chem B. 1906; 57(1):385-470.

27. Vijayaraghavan K, Yeong SY. Bacterial biosorbents and bisorption. Biotechnol Adv. 2008 May-Jun; 26(3):266-91. 